\title{
Tingkat Kecemasan Pasien Post Operasi yang Mengalami Fraktur Ekstremitas
}

\author{
Seviya Gani Maisyaroh, Urip Rahayu, Siti Yuyun Rahayu \\ Fakultas Keperawatan Universitas Padjadjaran \\ Email:urip_rahayu@yahoo.com
}

\begin{abstract}
Abstrak
Kecemasan merupakan salah satu masalah psikologis yang dialami oleh pasien fraktur ekstremitas setelah dilakukannya pembedahan. Kecemasan yang tidak teratasi akan berdampak pada lamanya proses penyembuhan, akan tetapi data kecemasan pasien post operasi masih belum jelas. Penelitian ini bertujuan untuk mengetahui tingkat kecemasan pasien post operasi fraktur ekstremitas berdasarkan karakteristik pasien. Metode dalam penelitian ini adalah deskriptif kuantitatif dengan jumlah sampel 46 orang yang diambil dengan teknik consecutive sampling. Pengumpulan data menggunakan kuesioner STAI (State-Trait Anxiety Inventory). Tingkat kecemasan dikategorikan menjadi ringan, sedang, dan berat. didapatkan bahwa state anxiety paling banyak berada pada tingkat sedang 54,3\% dan trait anxiety paling banyak berada pada tingkat ringan $60,9 \%$. Terdapat $46,4 \%$ responden yang memiliki state anxiety sedang berasal dari trait anxiety ringan. Berdasarkan karakteristik baik pada state anxiety ataupun trait anxiety, kecemasan berat dialami oleh pasien usia dewasa awal, perempuan, berpendidikan terakhir SMP dan SMA, bekerja sebagai pegawai swasta, belum pernah menjalani operasi sebelumnya, lokasi fraktur pada bagian ekstremitas bawah, dan merasakan nyeri sedang. Kondisi post operasi fraktur ekstremitas menjadi faktor yang dapat memengaruhi kecemasan. Terlihat dari pasien yang memiliki state anxiety yang sedang, memiliki trait anxiety yang ringan. Maka disarankan bagi perawat untuk melakukan pengkajian dan penanganan kecemasan terhadap state anxiety dan trait anxiety.
\end{abstract}

Kata kunci: Fraktur ekstremitas, post operasi, state anxiety, trait anxiety.

\section{Anxiety Levels of Patients with Extremity Fractures after Surgery}

\begin{abstract}
Anxiety is one of the psychological problems experienced by patients with extremity fractures after undergoing surgery. Anxiety that is not managed well will have an impact on the recovery process. However, anxiety in patients with extremity fractures is not well understood. The aim of this study was to determine the anxiety level of patients with extremity fractures after surgery based on the patients' characteristics. This study used descriptive quantitative method. Fourty six patients were recruited in this study by consecutive sampling technique. The data was collected by STAI (State-Trait Anxiety Inventory) quetionnaires. Anxiety levels were categorized into mild, moderate, and severe. The results showed that $54.3 \%$ of patients experienced state anxiety at a moderate level, and $60.9 \%$ had trait anxiety at a mild level. There were $46.4 \%$ of the patients whose moderate state anxiety originated from mild trait anxiety. Based on the characteristics of both state and trait anxiety, severe anxiety was experienced by young adults, women, patients with secondary school-level educational background, private employees, patients who have never had surgery before, patients with lower extremity fractures and patients in moderate pain. The postoperative state of extremity fractures is a factor that affects anxiety. Patients who had moderate state anxiety were found to also have mild trait anxiety. Thus, assessment and intervention of anxiety should be conducted on both state and trait anxiety.
\end{abstract}

Key words: Extremity fracture, post-operative, state anxiety, trait anxiety. 
Seviya Gani Maisyaroh: Tingkat Kecemasan Pasien Post Operasi

\section{Pendahuluan}

Kecelakaan lalu lintas di Indonesia setiap tahunnya meningkat. Terdapat peningkatan $21,8 \%$ dalam jangka waktu lima tahun. Dari jumlah total peristiwa kecelakaan yang terjadi, terdapat 5,8\% korban cedera atau sekitar delapan juta orang yang mengalami fraktur dengan jenis fraktur yang paling banyak terjadi yaitu fraktur pada bagian ekstremitas atas sebesar $36,9 \%$ dan ekstremitas bawah sebesar 65,2\% (Departemen Kesehatan Republik Indonesia, 2013).

Ketika seseorang mengalami fraktur ekstremitas, upaya untuk mengembalikan struktur dan fungsi tulang menjadi normal kembali salah satunya adalah dengan melakukan pembedahan. Menurut Suratun, dkk, (2008) masalah yang sering muncul segera setelah operasi, pasien telah sadar dan berada di ruang perawatan dengan edema/ bengkak, nyeri, imobilisasi, keterbatasan lingkup gerak sendi, penurunan kekuatan otot, pemendekan ektremitas, perubahan warna, serta penurunan kemampuan untuk ambulasi dan berjalan karena luka bekas operasi dan luka bekas trauma.

Selain masalah fisik di atas, pasien yang telah menjalani pembedahan umumnya akan mengalami masalah psikologis yaitu kecemasan. Menurut survey Depkes RI (2013), 15\% penderita fraktur mengalami stres psikologis dalam bentuk cemas. Thomas \& D'Silva (2012) mencatat $87 \%$ dari 60 orang yang mengalami fraktur ekstremitas bawah dan menjalani operasi terbuka mengalami kecemasan setelah operasi.

Kecemasan yang dialami dapat disebabkan oleh gejala-gejala yang muncul setelah dilakukan pembedahan, diantaranya yaitu rasa nyeri dan gangguan mobilisasi. Morris, dkk (2010), menjelasakan nyeri cukup berkontribusi terhadap aktivitas pasca bedah, nyeri pasca bedah ortopedi berada pada skala 4 sampai 7 walaupun dengan pemberian analgetik. Syahputra (2013) menemukan ada hubungan yang bermakna antara tingkat nyeri dengan tingkat kecemasan pada pasien dengan fraktur tulang panjang. Selain nyeri kondisi imobilisasi post operasi pada fraktur dapat menyebabkan kecemasan pada pasien. Asmadi (2009) menjelaskan bahwa kondisi immobilitas dapat memengaruhi emosional. Klien immobilisasi akan merasakan perubahan dalam konsep diri dan kecemasan tentang kondisi kesehatannya, serta faktor lain seperti masalah menurunnya kemandirian dan otonomi dalam melakukan aktivitas hidup sehari-hari.

Spielberger (1972, dalam Carducci, 2009) berpendapat bahwa kecemasan merupakan reaksi emosional yang tidak menyenangkan terhadap bahaya nyata yang disertai dengan perubahan sistem syaraf otonom dan pengalaman subjektif sebagai tekanan, ketakutan dan kegelisahan. Spielberger membedakan kecemasan menjadi dua yaitu state anxiety dan trait anxiety. State Anxiety adalah gejala kecemasan yang timbul apabila seseorang dihadapkan pada situasi yang dirasakan mengancam. Trait Anxiety adalah kecemasan yang menetap pada diri seseorang dan merupakan pembeda antara satu individu dengan individu lainnya.

Penelitian sebelumnya peneliti hanya fokus pada state anxiety, belum ada penelitian yang menjelaskan mengenai trait anxiety pada pasien post operasi fraktur ekstremitas. Dijelaskan bahwa terdapat hubungan antara kecemasan dasar (trait anxiety) dan kecemasan sesaat (state anxiety). Semakin berat kecemasan dasar (trait anxiety) akan membuat kecemasan sesaat (state anxiety) yang dialami oleh pasien lebih berat pula, maka dari itu dibutuhkan tindakan keperawatan untuk membantu pasien dalam mengontrol kecemasan sesaat (state anxiety) dengan mengatasi kecemasan dasar (trait anxiety) (Horikawa, M \& Akihiro, Y., 2012). Kedua kecemasan tersebut berpengaruh pada proses penyembuhan pasien. Oleh karena itu, pengkajian dan penanganan terhadap kecemasan dasar (trait anxiety) yang dimiliki oleh pasien menjadi penting untuk dilakukan oleh perawat.

Kecemasan yang timbul tersebut dapat dipengaruhi oleh karakteristik yang dimiliki oleh individu, yakni usia, pendidikan, jenis kelamin, pekerjaan, pengalaman operasi. Karakteristik tersebut merupakan sesuatu yang telah melekat dalam diri individu dan tidak dapat dirubah (Stuart, 2007; Kaplan \& Sadock 2010). Selain karakteristik tersebut nyeri dan lokasi fraktur juga dapat berpengaruh pada kecemasan individu. Walaupun karakteristik individu tersebut 
Seviya Gani Maisyaroh: Tingkat Kecemasan Pasien Post Operasi

merupakan sesuatu yang tidak dapat dirubah, namun dengan mengetahui karakteristik individu yang dapat membuat tingkat kecemasan menjadi lebih tinggi dapat menjadi pertimbangan bagi perawat dalam upaya pencegahan kecemasan yang lebih berat pada pasien post operasi fraktur ekstremitas.

Depkes RI (2008) menjelaskan bahwa kelompok individu yang bekerja cenderung lebih cemas dibandingkan dengan individu yang tidak bekerja, karena kondisi fraktur tentunya akan memengaruhi aktivitas pekerjaannya dikarenakan masa rehabilitasi atau masa penyembuhan yang memakan waktu yang lama. Selain itu, Depkes RI (2008) juga menjelaskan pada kelompok usia di bawah 30 tahun cenderung menunjukan respon cemas yang lebih berat dibandingkan kelompok usia di atasnya karena biasanya pada kelompok usia lebih dari 30 tahun telah terbentuk mekanisme koping yang baik.

Depkes RI (2008) tentang karakteristik lainnya yang memengaruhi kecemasan pada pasien fraktur yaitu kelompok individu dengan jenis kelamin perempuan cenderung lebih cemas dibandingkan kelompok individu laki-laki, hal ini terkait dengan penampilan yang biasanya adanya kejadian fraktur tersebut. Tentunya akan memengaruhi konsep dirinya. Penderita fraktur dengan tingkat pendidikan rendah cenderung menunjukan adanya respon cemas yang berlebihan mengingat keterbatasan mereka dalam memahami proses penyembuhan dari kondisi fraktur yang dialaminya. Penderita fraktur yang pernah menjalani operasi sebelumnya, tingkat kecemasan yang terjadi akan lebih ringan pada operasi yang selanjutnya. Pengalaman operasi ini juga berhubungan dengan kecemasan dasa (trait anxiety) yang dimiliki oleh pasien. Pengalaman merupakan salah satu faktor yang menentukan tingkat kecemasan dasar (trait anxiety) dari pasien.

Lokasi fraktur juga akan memengaruhi tingkat kecemasan pasien post operasi dengan fraktur. Gambatesa, dkk. (2013) menemukan pasien dengan hip fracture mengalami kecemasan sedang sampai dengan berat setelah dilakukan pembedahan. Sousa (2010) menemukan pasien dengan facial fracture mengalami kecemasan setelah pembedahan dan terdapat juga gangguan body image pada pasien. Hasil pada pasien fraktur ekstremitas akan berbeda, hal tersebut dikarenakan fungsi dari ekstremitas sebagai penopang tubuh, alat gerak dan bagian tubuh yang digunakan untuk melakukan kegiatan seharihari yang mendasar seperti berjalan, makan, menulis, mandi, dan aktivitas lainnya. Akan terdapat pula perbedaan tingkat kecemasan antara pasien fraktur pada ekstremitas atas dengan pasien fraktur pada ekstremitas bawah, sehubungan dengan fungsi dari masing-masing bagian pada ekstremitas dan beratnya gangguan mobilisasi yang diderita oleh pasien.

Kecemasan yang terjadi pada pasien post operasi fraktur dapat berdampak terhadap proses penyembuhan pasien. Ketika pasien fraktur ekstremitas mengalami kecemasan pada masa post operasi dan tidak teratasi dengan baik, maka akan berpengaruh pada lamanya proses penyembuhan. Roh, dkk. (2014) menemukan pada pasien fraktur ekstremitas terdapat hubungan antara kecemasan pada pasien dengan proses penyembuhan setelah tindakan pembedahan. Kecemasan yang terjadi dan tidak diatasi dengan baik akan berpengaruh pada proses rehabilitasi. Hal tersebut akan membuat proses recovery menjadi lebih lama. Selain itu, ketika seseorang tidak dapat mengatasi cemasnya dan berlanjut pada depresi hal tersebut juga akan berdampak kehidupan di masa depannya. Starr (2011) menjelaskan bahwa pada pasien trauma ortopedik, faktor psikologis merupakan faktor penting yang menentukan hasil fungsional dari pasien selain seberapa baik kita memperbaiki fraktur tersebut. Pasien dengan trauma ortopedik yang mengalami psychological distres hasil penyembuhan setelah cedera tidak akan sepenuhnya baik. Keadaan psikologis pasien akan terganggu dan hal tersebut akan berdampak pada pekerjaan di masa yang akan datang. Selain itu tidak hanya state anxiety saja yang dapat memengaruhi proses penyembuhan pasien fraktur ekstremitas, tetapi trait anxiety yang dimiliki oleh pasien pun dapat memengaruhi proses penyembuhan. Lagares., et al. (2014) menjelaskan bahwa trait anxiety yang dimiliki oleh pasien post operasi meningkatkan persepsi terhadap nyeri dan terdapat hubungan antara trait anxiety dengan penyembuhan yang tidak baik. Semakin tinggi trait anxiety maka 
akan berdampak pada proses penyembuhan, sehingga penyembuhan pun akan menjadi tidak baik.

Penelitian sebelumnya peneliti hanya berfokus pada state anxiety yang dialami oleh pasien post operasi fraktur ekstremitas. Pada penelitian ini akan dilihat bagaimana tingkat trait anxiety dan state anxiety yang dimiliki oleh pasien post operasi fraktur ekstremitas, karena keduanya memiliki hubungan yang salaing memengaruhi dan menentukan intervensi yang dapat diberikan pada pasien dengan kecemasan post operasi fraktur ekstremitas.

\section{Metode Penelitian}

Penelitian ini dilakukan di Rumah Sakit Khusus Bedah Halmahera Bandung. Rancangan penelitian adalah deskriptif kuantitatif dengan menggunakan kuesioner State Trait Anxiety Inventory. Kuesioner langsung diisi oleh responden dengan adanya pendampingan dari peneliti saat proses pengisian kuesioner. Populasi adalah seluruh pasien fraktur ekstremitas yang menjalani pembedahan di RSKB Halmahera Bandung. Sampel ditentukan dengan metode non probability sampling melalui consecutive sampling. Kriteria untuk sampel yaitu pasien post operasi fraktur ekstremitas yang berusia lebih dari 15 tahun dan tidak mengalami fraktur metacarpal dan metatarsal. Total responden yang didapatkan dalam jangka waktu satu bulan sesuai dengan kriteria yaitu
46 responden yang terdiri dari 22 orang pasien fraktur ekstremitas atas dan 24 orang pasien ekstremitas bawah.

Analisis data dilakukan dengan cara statistik deskriptif. Data yang didapatkan dikelompokan dalam tiga level kategori yaitu ringan, sedang, dan berat. Etika penelitian pada penelitian ini meliputi beneficience and non-maleficience dengan cara pengumpulan data tidak dilakukan pada saat pasien sedang kesakitan, mual, muntah, atau dalam kondisi yang tidak baik. Respect for confidentiality dengan cara responden hanya mencantumkan inisial nama saja dan data yang dikumpulkan hanya dilihat oleh peneliti. Respect for autonomy dengan cara peneliti memberikan inform consent kepada responden secara lisan maupun tulisan. Respect for justice dengan cara peneliti tidak membedakan perlakuan pada seluruh responden.

\section{Hasil Penelitian}

Hasil penelitian menunjukkan bahwa paling banyak responden mempunyai karakteristik berusia dewasa akhir sebanyak 23 orang $(50 \%)$, bejenis kelamin laki-laki 31 orang orang $(67,4 \%)$, berpendidikan terakhir SMA sebanyak 24 orang $(52,2 \%)$, bekerja sebagai pegawai swasta 13 orang $(28,3 \%)$, tidak pernah menjalani operasi sebelumnya sebanyak 27 orang $(58,7 \%)$, mengalami fraktur pada bagian ekstremitas bawah sebanyak 22 orang $(47,8 \%)$, dan merasakan nyeri sedang sebanyak 32 orang $(69,6 \%)$.

Tabel 1 Distribusi Responden menurut Tingkat State Anxiety pada Pasien Post Operasi Fraktur Ekstremitas

\begin{tabular}{lc}
\hline \multicolumn{1}{c}{ Tingkat State Anxiety } & Frekuensi \\
\hline Kecemasan Ringan & 18 \\
Kecemasan Sedang & 25 \\
Kecemasan Berat & 3 \\
\hline
\end{tabular}

Tabel 2 Distribusi Responden menurut Tingkat Trait Anxiety pada Pasien Post Operasi Fraktur Ekstremitas

\begin{tabular}{lc}
\hline \multicolumn{1}{c}{ Tingkat Trait Anxiety } & Frekuensi \\
\hline Kecemasan Ringan & 28 \\
Kecemasan Sedang & 15 \\
Kecemasan Berat & 3 \\
\hline
\end{tabular}


Seviya Gani Maisyaroh: Tingkat Kecemasan Pasien Post Operasi

Tabel di atas merupakan hasil tingkat state anxiety yang dikelompokkan menjadi tiga yaitu ringan, sedang, dan berat.

Tabel 1 menunjukkan distribusi tingkat State Anxiety sebagian besar pasien pada kecemasan sedang yaitu 25 orang $(54,3 \%)$, lainnya kecemasan ringan dan kecemasan berat. Distribusi Tingkat Trait Anxiety sebagian besar pasien pada kecemasan ringan yaitu 28 orang $(60.9 \%)$, lainnya kecemasan sedang dan kecemasan berat (tabel 2).

Responden remaja, dewasa awal dan dewasa akhir Post operasi ekstremitas

Tabel 3 Tabulasi Silang Tingkat State Anxiety dan Karakteristik Pasien Post Operasi Fraktur

\begin{tabular}{|c|c|c|c|c|c|c|}
\hline \multirow[t]{3}{*}{ Karakteristik Responden } & \multicolumn{6}{|c|}{ Tingkat State Anxiety } \\
\hline & \multicolumn{2}{|c|}{ Ringan } & \multicolumn{2}{|c|}{ Sedang } & \multicolumn{2}{|c|}{ Berat } \\
\hline & $\mathbf{F}$ & $\%$ & f & $\%$ & $\mathbf{F}$ & $\%$ \\
\hline \multicolumn{7}{|l|}{ Usia } \\
\hline Remaja (15-20 th) & 1 & 11,1 & 7 & 77,8 & 1 & 11,1 \\
\hline Dewasa awal (21-30 th) & 1 & 14,3 & 4 & 57,1 & 2 & 28,6 \\
\hline Dewasa akhir (31-60 th) & 11 & 47,8 & 12 & 52,2 & 0 & 0 \\
\hline Lansia (>60 th) & 5 & 71,4 & 2 & 28,6 & 0 & 0 \\
\hline \multicolumn{7}{|l|}{ Jenis Kelamin } \\
\hline Laki-laki & 12 & 38,7 & 18 & 58,1 & 1 & 3,2 \\
\hline Perempuan & 5 & 33,3 & 8 & 53,4 & 2 & 13,3 \\
\hline \multicolumn{7}{|l|}{ Pendidikan } \\
\hline $\mathrm{SD}$ & 1 & 50,0 & 1 & 50,0 & 0 & 0 \\
\hline SMP & 1 & 14,3 & 5 & 71,4 & 1 & 2,2 \\
\hline SMA & 9 & 37,5 & 13 & 54,2 & 2 & 4,3 \\
\hline Perguruan Tinggi & 7 & 53,8 & 6 & 46,2 & 0 & 0 \\
\hline \multicolumn{7}{|l|}{ Pekerjaan } \\
\hline Tidak bekerja & 4 & 66,7 & 2 & 33,3 & 0 & 0 \\
\hline PNS & 2 & 40,0 & 3 & 60,0 & 0 & 0 \\
\hline Pegawai swasta & 4 & 30,8 & 7 & 53,8 & 2 & 15,4 \\
\hline Wiraswasta & 6 & 66,7 & 3 & 33,3 & 0 & 0 \\
\hline Ibu rumah tangga & 1 & 20,0 & 4 & 80,0 & 0 & 0 \\
\hline Pelajar/Mahasiswa & 1 & 12,5 & 6 & 75,0 & 1 & 12,5 \\
\hline \multicolumn{7}{|l|}{ Pengalaman Operasi } \\
\hline Pernah & 8 & 42,1 & 11 & 57,9 & 0 & 0 \\
\hline Tidak pernah & 10 & 37,0 & 14 & 54,3 & 3 & 6,5 \\
\hline \multicolumn{7}{|l|}{ Lokasi Fraktur } \\
\hline Ekstremitas atas & 10 & 47,6 & 10 & 47,6 & 1 & 4,8 \\
\hline Ekstremitas bawah & 8 & 36,4 & 12 & 54,5 & 2 & 9,1 \\
\hline Multiple & 0 & 0 & 3 & 100 & 0 & 0 \\
\hline \multicolumn{7}{|l|}{ Tingkat Nyeri } \\
\hline Ringan & 4 & 66,7 & 2 & 33,3 & 0 & 0 \\
\hline Sedang & 12 & 37,5 & 17 & 53,1 & 3 & 9,4 \\
\hline Berat & 2 & 25,0 & 6 & 75,0 & 0 & 0 \\
\hline
\end{tabular}


Seviya Gani Maisyaroh: Tingkat Kecemasan Pasien Post Operasi

Tabel 4 Tabulasi Silang Tingkat Trait Anxiety dan Karakteristik Pasien Post Operasi Fraktur

\begin{tabular}{|c|c|c|c|c|c|}
\hline \multirow[t]{3}{*}{ Karakteristik Responden } & \multicolumn{5}{|c|}{ Tingkat Trait Anxiety } \\
\hline & \multicolumn{2}{|c|}{ Ringan } & \multicolumn{2}{|c|}{ Sedang } & \multirow{2}{*}{$\begin{array}{lr}\text { Berat } \\
\text { f }\end{array}$} \\
\hline & $\mathbf{F}$ & $\%$ & f & $\%$ & \\
\hline \multicolumn{6}{|l|}{ Usia } \\
\hline Remaja (15-20 th) & 5 & 55,6 & 3 & 33,3 & 1 \\
\hline Dewasa awal (21-30 th) & 2 & 28,6 & 3 & 42,9 & 2 \\
\hline Dewasa akhir (31-60 th) & 15 & 65,2 & 8 & 34,8 & 0 \\
\hline Lansia (>60 th) & 6 & 85,7 & 1 & 14,3 & 0 \\
\hline \multicolumn{6}{|l|}{ Jenis Kelamin } \\
\hline Laki-laki & 22 & 80,0 & 8 & 25,8 & 1 \\
\hline Perempuan & 6 & 40,0 & 7 & 46,7 & 2 \\
\hline \multicolumn{6}{|l|}{ Pendidikan } \\
\hline $\mathrm{SD}$ & 1 & 50 & 1 & 50 & 0 \\
\hline SMP & 3 & 42,9 & 3 & 42,9 & 1 \\
\hline SMA & 13 & 54,2 & 9 & 37,5 & 2 \\
\hline Perguruan Tinggi & 10 & 76,9 & 3 & 23,1 & 0 \\
\hline \multicolumn{6}{|l|}{ Pekerjaan } \\
\hline Tidak bekerja & 5 & 83,3 & 1 & 16,7 & 0 \\
\hline PNS & 3 & 60,0 & 2 & 40,0 & 0 \\
\hline Pegawai swasta & 6 & 46,2 & 5 & 38,5 & 2 \\
\hline Wiraswasta & 9 & 100,0 & 0 & 0 & 0 \\
\hline Ibu rumah tangga & 0 & 0 & 5 & 100,0 & 0 \\
\hline Pelajar/Mahasiswa & 5 & 62,5 & 2 & 25,0 & 1 \\
\hline \multicolumn{6}{|l|}{$\begin{array}{l}\text { Pengalaman Operasi } \\
\text { Sebelumnya }\end{array}$} \\
\hline Pernah & 12 & 63,2 & 7 & 36,8 & 0 \\
\hline Tidak pernah & 16 & 59,3 & 8 & 29,6 & 3 \\
\hline \multicolumn{6}{|l|}{ Lokasi Fraktur } \\
\hline Ekstremitas atas & 15 & 71,4 & 5 & 23,8 & 1 \\
\hline Ekstremitas bawah & 11 & 50,0 & 9 & 40,9 & 2 \\
\hline Multiple & 2 & 66,7 & 1 & 33,3 & 0 \\
\hline \multicolumn{6}{|l|}{ Tingkat Nyeri } \\
\hline Ringan & 6 & 100,0 & 0 & 0 & 0 \\
\hline Sedang & 18 & 56,3 & 11 & 34,4 & 3 \\
\hline
\end{tabular}

sebagian besar mengalami tingkat state anxiety sedang yaitu $7(77,8 \%), 4(57.1 \%)$, dan $12(52 \%)$ sedangkan pada lansia sebagian besar mengalami tingkat state anxiety Ringan yaitu $5(71,4 \%)$. Responden berdasarkan jenis kelamin, pendidikan, pekerjaan, pengalaman operasi, lokasi fraktur, tingkat nyeri sebagian besar mengalami tingkat state anxiety sedang lainnya tingkat state anxiety ringan dan berat. Responden remaja, dewasa akhir dan lansia Post operasi ekstremitas sebagian besar mengalami tingkat trait anxiety Ringan yaitu $5(55,6 \%), 15(65.2 \%)$, dan $6(85.7 \%)$ sedangkan pada Lansia sebagian besar 
Seviya Gani Maisyaroh: Tingkat Kecemasan Pasien Post Operasi

mengalamai tingkat trait anxiety sedang yaitu $3(42.9 \%)$. Responden berdasarkan jenis kelamin, pendidikan, pekerjaan, pengalaman operasi, lokasi fraktur, tingkat nyeri sebagian besar mengalami tingkat trait anxiety ringan lainnya tingkat trait anxiety ringan dan berat.

\section{Pembahasan}

Berdasarkan hasil penelitian dengan menggunakan kuesioner STAI (State-Trait Anxiety Inventory), tingkat kecemasan dasar (trait anxiety) yang paling banyak dimiliki oleh responden adalah tingkat kecemasan dasar (trait anxiety) ringan. Hasil penelitian tersebut dapat diartikan bahwa responden memiliki sifat pencemas ringan atau responden akan mengalami kecemasan sesaat (state anxiety) ketika mendapatkan stresor yang tinggi.

Kecemasan sesaat (state anxiety) yang dialami oleh pasien bisa dipengaruhi oleh kecemasan dasar (trait anxiety) yang dimiliki oleh pasien. Spielberger (1972, dalam Carducci 2009) menjelaskan bahwa stimulus yang mengancam dan menyebabkan timbulnya kecemasaan sesaat (state anxiety) dipengaruhi oleh sikap dan kemampuan serta kecemasan dasar (trait anxiety) yang sifatnya menetap dalam diri individu. Kecemasan dasar (trait anxiety) mengacu pada perbedaan kepribadian dalam kecenderungan mengalami kecemasan.

Hasil penelitian juga menunjukkan bahwa di antara responden yang memiliki tingkat kecemasan dasar (trait anxiety) ringan hampir setengah dari responden memiliki kecemasan sesaat (state anxiety) yang sedang. Hal tersebut menunjukkan bahwa tingginya tingkat kecemasan sesaat (state anxiety) dipengaruhi oleh tingkat kecemasan dasar (trait anxiety) yang dimiliki oleh responden dan tambahan stimulus atau stimulus yang besar yang berasal dari kondisi post operasi fraktur ekstremitas yang dialami oleh responden. Hasil tersebut sejalan dengan penelitian yang dilakukan oleh Horikawa \& Akihiro (2012) yang menjelaskan bahwa terdapat hubungan antara kecemasan dasar (trait anxiety) dan kecemasan sesaat (state anxiety). Semakin berat kecemasan dasar (trait anxiety) akan membuat kecemasan sesaat (state anxiety) yang dialami oleh pasien lebih berat pula, maka dari itu dibutuhkan tindakan keperawatan untuk membantu pasien dalam mengontrol kecemasan sesaat (state anxiety) dengan mengatasi kecemasan dasar (trait anxiety) Spielberger (1972, dalam Carducci 2009) menjelaskan bahwa kecemasan sesaat (state anxiety) melibatkan proses yang timbul karena adanya stimulus dari dalam (pikiran atau ide) maupun dari luar yang mengundang bahaya atau ancaman. Ketika stimulus dari luar semakin besar, maka semakin tinggi tingkat kecemasan sesaat (state anxiety) yang dialami oleh seseorang.

Jadi, selain kecemasan dasar (trait anxiety) yang memengaruhi tingkat kecemasan sasaat (state anxiety) pasien post operasi, terdapat faktor lain yaitu faktor stimulus dari luar berupa kondisi pasien fraktur ekstremitas setelah dilakukan pembedahan. Dari hasil penelitian didapatkan bahwa tingkat kecemasan sesaat (state anxiety) yang paling banyak dialami oleh responden adalah kecemasan sedang. Pasien yang mengalami kecemasan sesaat (state anxiety) sedang memiliki perasaan khawatir, takut, tegang, gelisah dalam rentang sedikit sampai cukup merasakan.

Kecemasan sesaat (state anxiety) sedang yang dialami oleh pasien post operasi fraktur ekstremitas dapat disebabkan oleh kekhawatiran mengenai kondisi setelah pembedahan dan pemikiran tentang masa rehabilitasi yang cukup lama sampai pasien bisa kembali pada aktivitas normalnya serta pengaruh dari gejala-gejala post operasi yang timbul. Hal tersebut seperti yang dijelaskan oleh Smeltzer \& Bare (2002) bahwa pasien pascaoperatif sering menandakan kekhawatiran tentang hasil pembedahan dan pemikiran tentang masa depannya. Selain itu, kecemasan post operasi pada pasien fraktur yang dialami juga dapat disebabkan oleh nyeri, ketidakberdayaan, dan gangguan mobilisasi.

Gejala-gejala yang timbul seperti nyeri dan gangguan mobilisasi ditunjukkan dari hasil penelitian. Dari hasil penelitian pasien paling banyak merasakan nyeri pada tingkat sedang. Tingkat nyeri ini sejalan dengan tingkat kecemasan yang dialami oleh pasien yaitu paling banyak pasien mengalami tingkat kecemasan sesaat (state anxiety) 
sedang. Hal ini menggambarkan keterkaitan antara nyeri yang dirasakan oleh responden dengan tingkat kecemasan yang dialami. Nyeri yang dirasakan seseorang bukan hanya memengaruhi kondisi fisiknya, tetapi juga memengaruhi kondisi psikologis. Nyeri memengaruhi komponen emosional pasien serta seringkali menimbulkan gejala berupa kecemasan. Persepsi terhadap nyeri dapat memengaruhi tingkat kecemasan seseorang. Syahputra, dkk. (2013) menjelaskan bahwa ada hubungan yang bermakna antara tingkat nyeri dengan tingkat kecemasan pada pasien dengan fraktur tulang panjang. Semakin tinggi tingkat nyeri seseorang maka semakin tinggi pula tingkat kecemasannya.

Lokasi fraktur bisa menjadi penentu beratnya gangguan mobilitas yang dialami oleh pasien. Gangguan mobilisasi tersebut menjadi penyebab kecemasan pada pasien. Hasil penelitian menunjukkan bahwa paling banyak pasien mengalami fraktur pada bagian ekstremitas bawah. Ketika seseorang mengalami fraktur pada bagian ekstremitas bawah maka gangguan mobilisasi yang dialami akan lebih besar dibandingkan dengan seseorang yang mengalami fraktur pada bagian ekstremitas atas dan lebih ringan dari pasien yang mengalami fraktur multiple, sehingga kecemasan sesaat (state anxiety) bersada pada tingkat sedang. Asmadi (2009) menjelaskan bahwa kondisi immobilitas dapat memengaruhi emosional. Klien immobilisasi akan merasakan perubahan dalam konsep diri dan kecemasan tentang kondisi kesehatannya, serta faktor lain seperti masalah menurunnya kemandirian dan otonomi dalam melakukan aktivitas hidup sehari-hari.

Kedua kecemasan yang dialami oleh pasien post operasi fraktur ekstremitas baik kecemasan dasar (trait anxiety) dan kecemasan sesaat (state anxiety) dapat berdampak terhadap proses penyembuhan pasien bila tidak diatasi dengan baik. Respon psikologis terhadap kecemasan akan berpengaruh pada tahap penyembuhan pasien fraktur ekstremitas. Roh, dkk. (2014) menemukan pada pasien fraktur ekstremitas terdapat hubungan antara kecemasan pada pasien dengan proses penyembuhan setelah tindakan pembedahan. Kecemasan akan membuat proses recovery menjadi lebih lama. Selain itu, ketika seseorang tidak dapat mengatasi cemasnya dan berlanjut pada depresi hal tersebut juga akan berdampak pada kehidupan di masa depannya.

Hubungan antara kecemasan sesaat (state anxiety) dan kecemasan dasar (trait anxiety) membuat kecemasan dasar (trait anxiety) pun berperan dalam proses lamanya penyembuhan apabila tidak diatasi. Kecemasan dasar (trait anxiety) ini jika dibiarkan begitu saja akan berakibat buruk bagi pasien yang sedang dalam kondisi tidak sehat dan menerima berbagai stimulus yang dapat menimbulkan gangguan psikologis. Stimulus-stimulus yang ditimbulkan akan menimbulkan kekhawatiran mengenai halhal di masa yang akan datang. Hal tersebut akan terus muncul dan berlangsung dalam jangka waktu yang lebih panjang. Lagares D.T., et al. (2014) menjelaskan bahwa trait anxiety yang dimiliki oleh pasien post operasi meningkatkan persepsi terhadap nyeri dan terdapat hubungan antara trait anxiety dengan penyembuhan yang tidak baik. Semakin tinggi trait anxiety maka akan berdampak pada proses penyembuhan, sehingga penyembuhan pun akan menjadi tidak baik.

Peran perawat pada saat post operasi sangat dibutuhkan, salah satunya untuk mengatasi kecemasan pasien agar proses penyembuhan dapat berjalan dengan baik. Intervensi dapat ditentukan dengan melihat penyebab yang ada. Apabila kecemasan yang muncul diakibatkan oleh tingkat kecemasan dasar (trait anxiety) yang dimiliki oleh pasien berat, maka intervensi dapat dilakukan dengan menangani kecemasan dasar (trait anxiety) untuk dapat mengontrol kecemasan sesaat (state anxiety). Hasil penelitian menunjukkan bahwa semua pasien dengan tingkat kecemasan dasar (trait anxiety) berat mengalami kecemasan sesaat (state anxiety) yang berat pula. Hal tersebut berarti pasien yang memiliki tingkat kecemasan dasar (trait anxiety) berat mempersepsikan stimulus yang ada sebagai sesuatu ancaman yang besar bagi dirinya meskipun stimulus tersebut merupakan stimulus yang ringan. Sehingga pasien mudah merasakan kecemasan sesaat (state anxiety) dengan intensitas dan frekuensi yang lebih tinggi. Selama ini 
Seviya Gani Maisyaroh: Tingkat Kecemasan Pasien Post Operasi

pengkajian keperawatan terhadap kecemasan dilakukan berfokus pada kecemasan sesaat (state anxiety). Yildiz U.F., Sacide Y.T., \& Ozge V., (2013) menjelaskan bahwa perawat diharapkan bisa melakukan pengkajian terhadap rasa nyaman dan kecemasan pasien dengan lebih holistik lagi untuk membuat pasien menjadi lebih nyaman dan kecemasan pun tidak akan mengganggu pada proses penyembuhan. Pengkajian tersebut juga akan membantu perawat dalam menentukan intervensi yang tepat, karena kecemasan dasar (trait anxiety) akan berbeda pada setiap individunya.

Setelah dilakukannya pengkajian, perawat dapat mengidentifikan masalah dan menentukan intervensi keperawatan yang tepat. Intervensi keperawatan pada kecemasan dasar (trait anxiety) diantaranya yaitu bantu pasien untuk mengidentifikasi perasaannya dan penyebab yang menimbulka kecemasan, jalin komunikasi terapeutik dengan pasien, bantu pasien untuk membuat solusi dari kekhawatiran-kekhawatiran yang dirasakan. Intervensi tersebut membutuhkan suatu support system yang dapat membantu pasien. Salah satu cara yang dapat dilakukan oleh perawat yaitu membuat lingkungan yang nyaman dan berpengaruh positif bagi pasien. Hal tersebut dapat dilakukan dengan memberikan dukungan sosial yang baik dengan melibatkan keluarga pasien dalam proses penyembuhan pasien selama masa rehabilitasi yang memerlukan waktu yang cukup lama. Kuraesin (2009) menemukan bahwa terdapat hubungan antara dukungan sosial dengan tingkat kecemasan pasien. Pasien yang mendapatkan dukungan dari orang-orang terdekatnya mengalami tingkat kecemasan yang ringan. Hal tersebut juga berkaitan dengan pernyataan dari Varcarolis, Carson \& Shoemaker (2006) bahwa lingkungan yang positif dan orangorang yang membawa pengaruh positif akan memungkinkan bagi seseorang untuk mengontrol kecemasan yang dialami.

Apabila faktor penyebab timbulnya kecemasan adalah faktor kondisi post operasi fraktur ekstremitas, maka intervensi dapat difokuskan kepada penanganan gejalagejala yang dapat menimbulkan kecemasan. Intervensi tersebut diantaranya mengurangi rasa nyeri dan mengatasi gangguan mobilisasi yang dialami oleh pasien.

Tindakan keperawatan dengan cara mengurangi rasa nyeri dapat mengurangi tingkat kecemasan yang dialami pasien. Hal ini dapat dilihat dari hasil penelitian yang menunjukkan bahwa pasien dengan tingkat nyeri ringan akan mengalami kecemasan yang ringan pula. Rantala (2014) menjelaskan bahwa masalah utama setelah pembedahan adalah nyeri. Intensitas nyeri post operasi yang berat terbukti berhubungan dengan kecemasan, hubungan antara kecemasan dan nyeri merupakan suatu hubungan timbal balik. Perawat berperan untuk mengatasi masalah nyeri dan kecemasan secara non-farmakologi. Ketika kecemasan diatasi maka tingkat nyeri pun akan berkurang. Salah satu cara yang bisa digunakan adalah tekhnik relaksasi nafas dalam dan terapi musik. Beberapa penelitian sebelumnya menjelaskan bahwa terapi musik cukup efektif untuk mengurangi kecemasan. Musik dapat menguragi kecemasan dan meningkatkan mood pasien post operasi.

Tindakan keperawatan lain yang dapat dilakukan adalah ambulasi dini. Immobilisasi menjadi penyebab meningkatnya kecemasan yang dialami oleh pasien. Hal ini terlihat dari hasil penelitian yang menunjukkan pasien yang mengalami fraktur di bagian ekstremitas bawah lebih berat tingkat kecemasannya dibandingkan dengan pasien yang mengalami fraktur pada bagian ekstremitas atas. Pada pasien fraktur ekstremitas bawah akan mengalami immobilisasi atau keterbatasan gerak yang lebih besar dibandingkan dengan pasien fraktur ekstremitas atas. Keterbatasan gerak inibisa diatasi dengan tindakan ambulasi dini yang tepat. Menurut Bass N. (2009) dalam penelitiannya setelah pembedahan pasien dengan fraktur akan mengalami penurunan kemampuan mobilisasi. Salah satu peran perawat pada pasien post operasi fraktur adalah mengatasi gangguan mobilisasi. Menurut Hoppenfeld \& Murthy (2011 dalam Ropyanto, 2011) penurunan fase inflamasi disertai program rehabilitasi seperti ROM dan ambulasi mendukung peningkatan status fungsional. Latihan memberikan stresor terhadap fase penyembuhan tulang dengan melakukan banyak mobilisasi maka pengembalian kekuatan dan fungsi otot sangat memungkinkan. Latihan tersebut dapat dilakukan pada hari kedua paska operasi. 
Seviya Gani Maisyaroh: Tingkat Kecemasan Pasien Post Operasi

\section{Simpulan}

Simpulan dari penelitian ini adalah pada pasien post operasi fraktur ekstremitas, kecemasan sesaat (state anxiety) paling banyak berada pada tingkat kecemasan sedang dan kecemasan dasar (trait anxiety) paling banyak berada pada tingkat kecemasan ringan. Terdapat hampir setengah dari responden memiliki tingkat kecemasan dasar (trait anxiety) ringan, tapi memiliki kecemasan sesaat (state anxiety) yang sedang. Hal tersebut menunjukan bahwa faktor kondisi pasien post operasi fraktur ekstremitas, dapat menjadi faktor yang menyebabkan tingkat kecemasan pasien tersebut meningkat dan menjadi lebih berat. Perawat diharapkan dapat melakukan pengkajian terhadap kecemasan yang dirasakan oleh pasien pada saat ini (state anxiety) dan kecemasan dasar (trait anxiety) yang dimiliki pasien post operasi fraktur ekstremitas. Penanganan pun dilakukan kepada kedua kecemasan yang dialami oleh pasien karena kedua kecemasan tersebut saling memengaruhi.

\section{Daftar Pustaka}

Asmadi. (2009). Tehnik prosedural keperawatan: Konsep dan applikasi kebutuhan dasar klien. Jakarta: Salemba Medika.

Bass, N. (2009). Care of the Patient with a Hip Fracture. Journal of Orthopaedic Nursing.

Carducci, B.J. (2009). The Psychology of Personality : Viewpoint, Research, and Application. New Jersey: John Wiley \& Son.

Departemen Kesehatan Republik Indonesia. (2008). Profil Kesehatan Indonesia. Kementerian Kesehatan Republik Indonesia. Jakarta.

Departemen Kesehatan Republik Indonesia. (2013). Riskesdas 2013 dalam Angka. Kementerian Kesehatan Republik Indonesia. Jakarta.

Gambatesa, M., et all. (2013). Counseling, quality of life, and acute postoperative pain in elderly patients with hip fracture. Journal of Multidisciplinary Healthcare.

Horikawa, M., \& Akihiro Y., (2012). The Relationships among Trait Anxiety, State Anxiety and the Goal Performance of Penalty Shoot-Out by University Soccer Players. Journal of Psychological Sciences.

Kaplan J.B., \& Sadock T.C. (2010). Sinopsis Psikiatri, Ilmu Pengetahuan Perilaku Psikiatri Klinis. Jakarta: Binarupa Aksara.

Kuraesin, N.D. (2009). Faktor-Faktor yang Memengaruhi Tingkat Kecemasan Pasien yang Menghadapi Operasi di RSUP Fatmawati. Universitas Islam Negeri Syarif Hidayatullah Jakarta.

Lagares, D.T., et al. (2014). Influence of State Anxiety and Trate Anxiety in Postoperative in Oral Surgery. Journal of University of Seville Spain.

Morris, B.A, et al. (2010). Clinical Practice Guidelines for Early Mobilization Hours After Surgery. Journal of Orthopaedic Nursing.

Rantala, M. (2014). Nurses' Evaluations of Postoperative Pain Management in Patients with Dementia. University of Eastern Finland.

Roh, Y. H., dkk. (2014). Effect of Anxiety and Catastrophic Pain Ideation on Early Recovery After Surgery for Distal Radius Fractures. The Journal of Hand Surgery.

Ropyanto, C. B. (2011). Analisis FaktorFaktor yang Berhubungan dengan Status Fungsional Pasien Paska ORIF Fraktur Ekstremitas Bawah di RS. Ortopedi Prof. Soeharso Surakarta. Universitas Indonesia.

Smeltzer, S., \& Bare, B. (2002). Keperawatan Medikal Bedah. Jakarta: EGC.

Sousa, A. D. (2010). Psychological Issues in Acquired Facial Trauma. Indian Journal of Plastic Surgery.

Starr, J. A. (2011). Fracture Repair: 
Seviya Gani Maisyaroh: Tingkat Kecemasan Pasien Post Operasi

Successful Advances, Persistent Problems, and the Psychological Burden of Trauma. The Journal of Bone and Joint Surgery.

Stuart, G. W. (2007). Buku Saku Keperawatan Jiwa, Edisi 5. Jakarta: EGC.

Suratun, dkk. (2008). Seri Asuhan Keperawatan : Klien Gangguan Sistem Muskuloskeletal. Jakarta: EGC.

Syahputra, H. (2013). Hubungan Tingkat Nyeri Dengan Tingkat Kecemasan Pada Pasien Fraktur Tulang Panjang Di Rsud Arifin Achmad Pekanbaru. Universitas Riau
Thomas, A.A., \& D'Silva, F. (2012). Pain, Anxiety \& Functional Status Of Patients With Lower Limb Fracture And Dislocation After Open Reduction. Nitte University Journal of Health Science.

Varcarolis, E.M., Carson,V.B., \& Shoemaker, N.C. (2006). Foundation of Psychiatric Mental Heatlh Nursing. Philadelphia: Elsevier's Health Science Department.

Yildiz, U.F., Sacide Y.T., Ozge V. (2013). Effects of Drains on Pain, Comfort and Anxiety in Patients Undergone Surgery. International Journal of Caring Sciences. 